\author{
A.B. RIABOV $V^{1,2}$, M.S. KUBIROV $V^{2}$ A.V. KHIZHNIKOV $V^{3}$, M.YU. RYKOV \\ ${ }^{1}$ National Medical Research Radiological Centre, Moscow, Russian Federation; \\ ${ }^{2}$ Morozov Children Municipal Clinical Hospital, Moscow, Russian Federation; \\ ${ }^{3}$ Scientific and Clinical Center for Children and Adolescents of the Federal Medical and Biological Agency of Russia, Moscow, Russian Federation; \\ ${ }^{4}$ Tver State Medical University, Tver, Russian Federation
}

\title{
Laparoscopic resections in the treatment of children with liver tumors: the first experience
}

Relevance: Surgery is one of the main methods of treating patients with liver neoplasms. At that, minimally invasive surgical techniques facilitate the course of the postoperative period and rehabilitation.

The purpose of the study was the selection of optimal surgical treatment for children with liver tumors.

Results: In 2014-2020, five patients aged 3-9 years with liver tumors underwent laparoscopic resection at the Morozovskaya Children's City Clinical Hospital (Moscow, Russia). Out of 3 patients with hepatoblastomas, two patients had stage PRETEXT I, one - stage II. All patients underwent radical surgical treatment (R0); in one child(4\%), the resection volume was $R 1$. The duration of operations did not exceed 60 minutes; intraoperative blood loss was within $10 \mathrm{ml} / \mathrm{kg}$; no intraoperative complications were registered.

Conclusion: Laparoscopic techniques reduce surgery time and blood loss, prevent intraoperative and postoperative complications, shorten the hospital stay, decrease enteral and drug burden, and the need for chemotherapy. They also facilitate radical surgery and early patient mobilization.

Keywords: pediatric oncology, surgery, laparoscopy, surgical oncology, hepatoblastoma, case report, liver, laparotomy.

Introduction: The number of patients with neoplasms of various localizations and etiologies is increasing due to the development of imaging techniques and improved follow-up standards. Liver lesions are among the leaders in this nosology due to the primary lesion localization in the organ parenchyma and metastatic involvement. The most optimal method for treating patients with liver tumors is surgery. Modern medicine aims to reduce the trauma associated with the treatment of many diseases, for example, by developing and introducing minimally invasive surgical techniques that facilitate the postoperative period and rehabilitation. This is especially essential in pediatric practice.

For centuries, the liver has been one of the most mysterious organs, and surgical interventions on it have often been lethal [1]. This was due to a lack of knowledge about the anatomy of this organ and the pathophysiology of the disease.

In 1654, F. Glissonii described the portal vein stem architectonics - a portal triad later called "Glisson's system." In 1888, H.Rex studied the segmental liver structure. In 1898, Cantlie described an actual boundary between the lobes. In 1911, Wendel performed the first successful anatomical right-sided hemihepatectomy [2]. In Russia, the first successful liver resection was performed in 1889 in a patient with fibroma by N.V. Sklifosovsky. In 1894, M.M. Kuznetsov and V.R. Penski suggested liver sutures [3]. In 1908 , an Irish surgeon S.H. Pringle invented the hepatodu- odenal ligament's temporary clamping, which reduced the complication rate.

Later, techniques of liver resections were developed using the principles of preliminary ligation of the vascularly isolated elements of different liver zones (lobe, segment) or their pole ligation (fissural method), which allowed to perform more radical operations [4-6].

The first report on laparoscopic atypical liver resection for focal masses of solid nature was published in 1991 by Reich et al. [7].

A limited number of observations in pediatric patients with liver tumors urges the development of minimally invasive surgical techniques for this group of patients.

Purpose of the study: was a selection of the optimal surgical treatment for children with liver tumors.

Materials and Methods: In 2014-2020, five patients (three boys (60\%) and two girls (40\%)) aged 3 to 9 years with liver tumors who underwent laparoscopic resection were treated at Morozov Children's City Clinical Hospital (Moscow, Russia). Hepatoblastomas were registered in $3(60 \%)$ patients, adenomas and hamartomas - in 1 (20\%) patient each.

- Preoperative examination of the patients included:

- Determination of cancer-specific marker levels (AF, HCG);

- Ultrasound with the assessment of tumor topography and angioarchitecture;

- CT scan with intravenous contrast;

- MRI with intravenous contrast. 
Results: Hepatoblastoma was registered in stage PRETEXT I in two patients and stage II in one patient.

All patients underwent radical surgical treatment (R0); in one child (4\%), the resection volume was R1.

During laparoscopic surgery, bisegmentectomy was performed in two cases and segmentectomy in three cases.

During the surgical intervention, preference was given to various modern methods of achieving hemostasis: monopolar coagulation, bipolar coagulation (including measuring tissue impedance). High-velocity water jet dissection has been used repeatedly in the experience stages of this field, but today ultrasound dissection is the preferred method.

The duration of laparoscopic operations was 30 to $60 \mathrm{~min}$ utes. Other results are shown in Table 1.
Table 1 - Laparoscopic surgery results in children with liver tumors

\begin{tabular}{|l|c|}
\hline \multicolumn{1}{|c|}{ Indicators } & Values \\
\hline Duration of operation, $\mathrm{min}$ & $30-90$ \\
\hline The volume of blood loss, $\mathrm{ml} / \mathrm{kg}$ & not more than 10 \\
\hline Intraoperative haemotransfusion & $0(0)$ \\
\hline Intraoperative complications, including: & $0(0)$ \\
\hline Lethality & $0(0)$ \\
\hline Damage of extrahepatic biliary tract & $0(0)$ \\
\hline Total & 5 \\
\hline
\end{tabular}

The postoperative characteristics are shown in Table 2.

Table 2 - Postoperative course in children with liver tumors after laparoscopic surgery

\begin{tabular}{|l|c|}
\hline \multicolumn{1}{|c|}{ Indicators } & Values \\
\hline Duration of stay in ICU, days & $1-3$ \\
\hline Timing of patient activation (start of enteral load, verticalization) & from 1 p/o day \\
\hline Duration of stay in hospital, days & $5-8$ \\
\hline Number of bed-days before chemotherapy after surgery & 8 \\
\hline Duration of abdominal drainage, days & up to 3-4 \\
\hline Duration of antibiotic therapy, days & $7-10$ \\
\hline Duration of analgesia, days & $1-3$ \\
\hline Duration of fermentation, days & up to 4 \\
\hline Complications, $n(\%)$ & 0 \\
\hline
\end{tabular}

Discussion: $\mathrm{CT}$ and MRI scanning provide the most accurate assessment of the extent of tumor invasion. In addition, they can be used to perform non-invasive volumetry in patients with advanced tumor progression (PRETEXT III) and to predict possible postoperative complications.

Currently, the diagnosis can be made without morphological verification based on the level of cancer-specific markers. In two patients, the diagnosis was verified by the clinical picture. Morphological verification of the diagnosis was required in 3 cases. For this purpose, a percutaneous hepatic aspiration or "true-cut" biopsy under ultrasound navigation was used in two children, and a laparoscopic biopsy was performed in one.

An essential advantage of the laparoscopic technique is the reduced trauma and rehabilitation time and low blood loss, which undoubtedly meets all the requirements of modern surgery.

Principles of laparoscopic surgery for focal liver lesions include using specialized equipment such as a dissector and a hemostasis device and choosing the optimal volume of surgery: atypical resections of "anterior" segments (III-VI) or bisegmentectomies in relatively small focal lesions.

Resection of "complicated" segments (VII-VIII) is possible using special equipment that can change the angle of curvature of the working zone.

Today, there are several ways to classify this type of surgery depending on the resection method, volume, access, and extent.

Literature analysis shows that laparoscopic wedge resection of the liver is the most frequently performed (45\%).
Next in frequency are anatomic left lateral section (20\%), right-sided hemihepatectomy (9\%), left hemihepatectomy (7\%), 19 extended right hemihepatectomies $(0.7 \%), 3$ extended left hemihepatectomies $(0.1 \%), 18$ caudal lobectomies $(0.6 \%), 8$ central resections $(0.3 \%)$. These statistics have been compiled by foreign colleagues involved in the treatment of adults [7-9].

Contraindications to the laparoscopic method are cardiac defects associated with the risk of decompensation during surgical treatment in pneumoperitoneum; coagulopathies complicated by thrombosis of visceral vessels of the abdominal cavity; sub-compensated respiratory failure; excess body weight; widespread adhesions in the abdomen.

Among the presented complications, bile leakage, the possibility of massive intraoperative bleeding, and the risk of gas embolism are the most common. It is also worth pointing out the technical complexity of performing various surgical maneuvers using laparoscopy. Let us describe some of the complications in more detail.

The volume of intraoperative blood loss during laparoscopic operations is 7 times less than during open surgery. Postoperative complications of open operations were observed in 17 (51.5\%) cases and required more prolonged treatment, while after using laparoscopic surgery, a complicated course was observed in 13 (35.1\%) patients [10].

The duration of stay in ICU is 3-5 days for open operations and does not exceed three days for laparoscopic operations. Enteral load, verticalization of the patient in laparoscopic surgeries are possible earlier (starting from Day 1 after surgery). In the postoperative period, chemother- 
apy was started on the 8th day with minimally invasive surgery, which reduces the number of bed days before post-surgery chemotherapy. Children were anesthetized in the postoperative period using combined anesthesia and prolonged epidural anesthesia. During laparoscopic liver resection, the duration of analgesia (1-3 days) and antibiotic therapy (7-10 days) was almost twice less than during laparotomy (3-5 and 12-14 days, respectively). Abdominal drainage and fermentation continued for a maximum of 4 postoperative days.

No clinical cases after laparoscopic surgery were associated with lethal outcomes, repeated surgical interventions, or blood transfusions. The main proportion of complications was fluid accumulation in the operative zone, noted in $8(47.1 \%)$ patients. Five patients could be treated using conservative therapy, and three were treated with aspiration. Hydrothorax developed in 6 (35.3\%) patients in the postoperative period. A single pleural puncture managed this complication. Lower lobe pneumonia on the side of the operation developed in 1 (5.9\%) patient. Another $1(5.9 \%)$ patient developed suppuration of the postoperative wound $[11,12]$.

The duration of hospital treatment ranged from 1.2 to 15.3 days. It varied by both the access method (in laparotomy - about five days, in laparoscopy - about one day after surgery) and the hospital stay (in the USA - 1.9 to 2.9 days, in Europe - 3.5 to 8.3 days, in Asia - 4.0 to 14.9 days). The average hospitalization time was four days, on average two days less than after open surgery. It should be noted that there are no data on the correlation between the volume of resection and the duration of hospital stay in the world literature [11, 12].

According to our review of the literature, the average operative time is 360 minutes. In the postoperative period, $12 \%$ of cases required observation in the intensive care unit, and one patient died from concomitant pathology. The initiation of oral analgesia and physical activity is earlier with the minimally invasive technique [13].

In the pediatric group of patients, the indications for liver resection are the presence of liver neoplasms, metastatic lesions, liver trauma, and cystic lesions.

The following cases of complications were described in the pediatric group: seroma formation (2.8\%), formation of hypertrophic scar (2.8\%). Infectious complications developed in 5.6\% [13].

Advances in technology and improved techniques have enabled robot-assisted techniques to be applied in pediatric surgery. According to Reich et al., blood loss, complications, and postoperative mortality after robot-assisted surgery do not differ from laparoscopic surgery [7]. The disadvantages of robot-assisted techniques are the long duration of surgery and the high cost of the equipment [13].

Thus, summarizing the literature data and based on the experience and results of surgeries performed at Morozov Children's City Clinical Hospital, the laparoscopic technique should be preferred for liver resection in patients with benign masses and PRETEXT I-II hepatoblastoma. When performing liver resection by this method, it is critical to use $10-\mathrm{mm}$ optics for adequate visualiza- tion, to perform preliminary volumetric marking of resection borders and monopolar dissection in the coagulation mode for parenchyma dissection, safe ligation of vascular structures using impedance bipolar coagulation techniques, continuous smoke evacuation by aspiration or through the elevated trocar valve; apply various methods of intraoperative hemostasis according to the nature and intensity of bleeding, retrieve the resectate in the endometrium without fragmentation through the mini-laparotomy access.

Minimally invasive techniques can be used to operate children with PRETEXT III hepatoblastoma, but further experience in this field and a comparative analysis of treatment outcomes are needed.

We do not recommend performing hemihepatectomy and dilated hemihepatectomy using laparoscopic technique.

Laparoscopic resection has become the gold standard for treating tumors in adult patients with HCC awaiting liver transplantation [13].

Conclusions: The use of laparoscopic techniques can reduce surgical time, reduce blood loss and prevent the development of complications intraoperatively and in the postoperative period, reduce the duration of hospital treatment, initiate early patient mobilization, enteral load, chemotherapy, reduce the drug load, and perform radical surgery.

Of course, there are indications and contraindications for each method. Laparoscopic techniques are not the standard of care for patients with liver tumors, but the results justify further studies to develop optimal treatment tactics.

\section{References:}

1. Alperovich B.I. Xirurgiya pecheni. - Tomsk: Izdatel'stvo Tomskogo universiteta, 1983. - 352 s. [Alperovich B.I. Liver surgery. - Tomsk: Tomsk University Publishing House, 1983. - 352 p.] (in Russian);

2. Wendel W. Beitrage zur Chiryrgie der Leber // Arch. Clin. Chir. - 1911. - Vol. 95. - P. 887.

3. Kuznetsov M.M., Pensky Yu.R. O sposobax rezekcii pecheni // Hirurgicheskij vestnik. - 1894. - № 12 (10-11). - S. 711-731 [Kuznetsov M.M., Penskiy Yu.R. About methods of liver resection // Surgical Bulletin. - 1894. - Vol. 12 (10-11). - P. 711-731] (in Russian);

4. Dykhno A.M. K voprosu ob obshirnyx rezekciyax pecheni // Vestnik khirurgii. - 1955. - №4. - S. 117-119 [Dykhno A.M. On the issue of extensive liver resections // Bulletin of Surgery. - 1955. - Vol. 4. - P. 117-119] (in Russian);

5. Zarivchatsky M.F., Mugatarov I.N., Kamenskikh E.D., Kosyak A.A., Gavrilov O.V., Malginov K.E., Kolevatov A.P. Profilaktika $i$ lechenie oslozhnenij pri rezekciyax ochagovyx obrazovanij pecheni // Annaly xirurgicheskoj gepatologii. - 2013. - № 18(3). - S. 4753 [Zarivchatsky M.F., Mugatarov I.N., Kamenskikh E.D., Kosyak A.A., Gavrilov O.V., Malginov K.E., Kolevatov A.P. Prevention and treatment of complications during resections of focal liver formations // Annals of Surgical Hepatology. - 2013. - Vol. 18 (3). P. 47-53] (in Russian);

6. Shirabe K., Kajiyama K., Harimoto N., Tsujita E., Wakiyama S., Maehara Y. Risk factors for massive bleeding during major hepatectomy // Wld. J. Surg. - 2010. - Vol. 34 (7). - P. 15551562. https://www.scopus.com/record/display.uri?eid=2-s2.077955468017 \&origin=inward\&txGid=89028a06d51 cb6f1ee957eb5 abf9d6a9; 
7. Reich H., McGlynn F., DeCaprio J., Budin R. Laparoscopic excision of benign liver lesions // Obstet Gynecol. - 1991. - Vol. 78 (5 Pt 2). - P. 956-958. https://pubmed.ncbi.nlm.nih.gov/1833688/;

8. Reggiani P., Antonelli B., Rossi G. Robotic surgery of the liver: Italian experience and review of the literature // Ecancermedicalscience. - 2013. - Vol. 7. - P. 358. https://dx.doi. org/10.3332/ecancer.2013.358;

9. Cherqui D., Husson E., Hammoud R., Malassagne B., Stéphan F., Bensaid S., Rotman N., Fagniez P.L. Laparoscopic liver resections: a feasibility study in 30 patients // Ann Surg. - 2000. - Vol. 232(6). - P. 753-762. https://doi.org/10.1097/00000658-200012000-00004;

10. Chen D.X., Wang S.J., Jiang Y.N., Yu M.C., Fan J.Z., Wang X.Q. Robot-assisted gallbladder-preserving hepatectomy for treating S5 hepatoblastoma in a child: A case report and review of the literature
// World J Clin Cases. - 2019. -Vol. 7(7). - P. 872-880. https://dx.doi. org/10.12998\%2Fwjcc.v7.i7.872;

11. Kwon H., Lee J.Y., Cho Y.J., Kim D.Y., Kim S.C., Namgoong J.M. How to safely perform laparoscopic liver resection for children: $A$ case series of 19 patients // J. Pediatr. Surg. - 2019. - Vol. 54(12). - P. 2579-2584. https://doi.org/10.1016/j.jpedsurg.2019.08.030;

12. Kim T., Kim D.Y., Cho M.J., Kim S.C., Seo J.J., Kim I.K. Use of laparoscopic surgical resection for pediatric malignant solid tumors: a case series // Surg. Endosc. - 2011. - Vol. 25(5). - P. 1484-1488. https://doi.org/10.1007/s00464-010-1418-y;

13. Veenstra M.A., Koffron A.J. Minimally-invasive liver resection in pediatric patients: initial experience and outcomes//HPB (Oxford). - 2016. - Vol. 18(6). - P. 518-522. https://dx.doi.org/10.1016\%2Fj. hpb.2015.11.004.

\section{ТҰЖЫРЫМ}

\section{А.Б. Рябов ${ }^{1,2}$, М.С. Кубиров ${ }^{2}$, А.В. Хижников ${ }^{3}$, М.Ю. Рыков}

1Ресей денсаулық сақтау министрлігінің «Радиология Ұлттық медициналық зерттеу орталығы» ФМБМ, Мәскеу, Ресей;

${ }_{2}$ «Мскеу қаласының Денсаулық сақтау департаментінің Морозов қалалық балалар клиникалық ауруханасы» ДСМБМ, Мәскеу, Ресей;

з «есей федералды медициналық-биологиялық агенттігінің балалар мен жасөспірімдердің ғылыми-клиникалық орталығы», Мәскеу, Ресей

${ }^{4}$ Ресей денсаулық сақтау министрлігінің «Тверь мемлекеттік медицина университеті» ФМБЖ КББМ Росс, Тверь, Ресей

\section{Бауыр ісігімен ауыратын балаларды емдеудегі лапароскопиялық резекциялар: алғашқы тәжірибе}

Өзектілігі: бауыр ісіктерімен ауыратын науқастарды емдеудің негізгі әдістерінің бірі хирургиялық болып табылады. Бұл ретте аз инвазивті хирургиялық техникалар операциядан кейінгі кезеңнің өтуі мен оңалтуды жеңілдетеді.

Зерттеу мақсаты: бауыр ісіктерімен ауыратын балаларды емдеуде оңтайлы хирургиялық қол жетімділікті таңдау.

Нәтижелері: 2014-2020 жылдары Морозов қалалық балалар клиникалық ауруханасында (Мәскеу, Ресей) бауыр ісіктерімен ауыратын 3-9 жас аралығындағы бес науқасқа лапароскопиялық резекция жасалды. Гепатобластомасы бар 3 пачиенттің ішінен PRETEXT-тің I-сатысы 2 пачиентmе, PRETEXT-тің II-сатысы 1 пачиентте байқалды. Барлық пачиенттерге түбегейлі ота жасалып, емдеу (RO) жүргізілді, 1 (4\%) балада резекция көлемі R1 құрады. Операчиялардың ұзақтығы 60 минуттан аспады, интраоперачиялық қан жоғалту көлемі 10 мл/кг болды, ота кезінде интраоперациялық асқынулар байқалмады.

Қорытынды: лапароскопиялық технологияларды қолдану операчия уақытын қысқартуға, қан жоғалту көлемін азайтуға және операциядан кейінгі және операциядан кейінгі кезеңдегі асқынулардың дамуына жол бермеуге, стационарлық емдеу уақытын қысқартуға, науқасты ерте жұмылдыруды, ішек жүктемесін, химиотерапияны бастауға, дәрі-дәрмек жүктемесін азайтуға, сондай-ақ түбегейлі операцияны жүргізуге мүмкіндік береді.

Түйінді сөздер: балалар онкологиясы, хирургия, лапароскопия, хирургиялық онкология, гепатобластома, клиникалық жағдай, бауыр, лапаротомия.

\section{АННОТАЦИЯ}

\section{А.Б. Рябов ${ }^{1,2}$, М.С. Кубиров ${ }^{2}$ А.В. Хижников ${ }^{3}$, М.Ю. Рыков}

1ФГБУ «Национальный медицинский исследовательский центр радиологии Минздрава России, Москва, Россия;

${ }^{2}$ ГБУЗ «Морозовская детская городская клиническая больница Департамента здравоохранения города Москвы», Москва, Россия; ${ }^{3}$ Научно-клинический центр детей и подростков

Федерального медико-биологического агентства России, Москва, Россия; ${ }^{4}$ ФГБОУ В0 «Тверской государственный медицинский университет» Минздрава России, Тверь, Россия

\section{Лапароскопические резекции \\ при лечении детей с опухолями печени: первый опыт}

Актуальность: Один из основных методов лечения пациентов с новообразованиями печени - хирургический. При этом малоинвазивные хирургические техники облегчают течение послеоперационного периода и реабилитацию.

Цель исследования: Выбор оптимального хирургического доступа при лечении детей с опухолями печени.

Результаты: В 2014-2020 г2. в Морозовской ДГКБ (Москва, Россия) у пяти пациентов в возрасте 3-9 лет с опухолями печени была выполнена лапароскопическая резекция. Из 3 пациентов с гепатобластомами, стадия PRETEXT I отмечена у 2 пациентов, II - у 1. У всех пациентов выполнено радикальное оперативное лечение (RO), у 1 (4\%) ребенка объем резекиии составил R1. Длительность операций не превышала 60 минут, объем интраоперационной кровопотери не превышал 10 мл/ кг, интраоперационные осложнения отмечены не были.

Заключение: Применение лапароскопических технологий позволяет сократить время операций, снизить объем кровопотери и предотвратить развитие осложнений как интраоперационно, так и в послеоперационном периоде, сократить сроки стационарного лечения, начать раннюю мобилизацию пациента, энтеральную нагрузку, химиоте рапию, снизить лекарственную нагрузку, а также провести радикальную операцию.

Ключевые слова: детская онкология, хирургия, лапароскопия, хирургическая онкология, гепатобластома, клинический случай, печень, лапаротомия. 